\title{
Studies on Chemical, Textural and Sensory Characteristics of Market and Laboratory Peda Samples Manufactured in Raipur City of Chhattisgarh
}

\author{
KAVITA BANJARE ${ }^{1 *}$, MANIKANT KUMAR ${ }^{2}$, B.K. GOEL ${ }^{3}$ and S. UPRIT 3 \\ ${ }^{1}$ Central Research Laboratory, I.G.K.V., Raipur, Chhattisgarh - 492012, India. \\ ${ }^{2}$ Department of R \& D, Tropilite Foods Pvt. Ltd., Gwalior, India. \\ ${ }^{3}$ Department of Dairy Technology, College of Dairy Technology, Raipur, Chhattisgarh, India. \\ ${ }^{*}$ Corresponding author E-mail: kavita.codt@gmail.com
}

http://dx.doi.org/10.13005/ojc/310125

(Received: December 05, 2014; Accepted: January 15, 2015)

\begin{abstract}
The study was conducted to characterize the chemical, textural and sensory quality attributes of market and laboratory made peda samples. Five market peda samples from the Vicinity of the traditional manufacturing shops were selected randomly for the study from different region of Raipur city, five manufacturers manufacturing and selling the product and having good popularity among consumers were selected and the study were replicated four times. Market peda samples were collected and simultaneously one peda sample was prepared in laboratory from khoa. These different peda samples were evaluated on the basis of their chemical, textural and sensory quality. The chemical composition of different peda samples had moisture, fat, total solid and titratable acidity content ranged from 12.22 to $23.34 \%, 12.26$ to $22.58 \%, 76.67$ to $87.78 \%$ and 0.37 to $0.63 \%$ respectively. The textural studies of market and laboratory made peda samples revealed that hardness, adhesiveness, cohesiveness, springiness, gumminess and chewiness ranged from 397.50 to $3417.71 \mathrm{~g},-70.15$ to $-1.38 \mathrm{~g} . \mathrm{s}, 0.094$ to $0.159,0.12$ to $0.20 \mathrm{~mm}, 13.08$ to $385.41 \mathrm{~g}$ and 1.53 to $53.43 \mathrm{~g} . \mathrm{mm}$ respectively. In sensory characteristics viz. flavor, color \& appearance, body \& texture and total score showed significant $(\mathrm{P}<0.01)$ difference between peda samples.
\end{abstract}

Key words: Peda, Chemical, Sensory, Textural characteristics, market samples.

\section{INTRODUCTION}

India produces about 140.6 million tons of milk annually, According to Prasad et al, (2012), about $50 \%$ of milk out of total production is converted to various traditional dairy products. Khoa is major product produced by heat desiccation of milk. It is made of either dried or whole milk thickened by heating it in an open iron pan (Londhe and Pal, 2008). Khoa is used as base material for production of peda. Peda is an indigenous khoa based heat desiccate milk sweet prepared by heating mixer of 
khoa and sugar with addition of natural and/ or artificial color and flavor until the desired characteristics texture and flavor develops. The quantity of peda produced in India far exceeds any other indigenous milk based sweets (Mahadevan, 1991). Peda is more popular than all other khoa based sweets. The reason is that peda is consider being a pure food and offered as "Prasad" during religious worships in Hindu temples as well as on religious celebrations (Narwade, 2007). Several types of pedas viz. plain, kesar and brown (Mathura peda) etc. are available in the market. Brown peda like Mathura peda, dharwad peda, mishra peda etc. are characterized by caramelized flavor and are popular due to their pleasant taste and comparatively longer shelf life (Londhe and pal, 2008). Wide variation in the quality have been reported with respect to physico-chemical, rheological and sensory profiles depending on manufacturing technique employed, type and quality of base material (milk/khoa) used, added coloring and flavoring substances, individual skills, trade practices and consumers preferences (Patel, 2011). The instrumental method of texture assessment aims at quantifying objectively the textural characteristics. The textural characteristics of peda are greatly influenced by its composition, type \& quality of raw material used and manufacturing practices/ parameters followed used. The present communication is a preliminary report on the chemical, texture and sensory profile of both peda samples sold in different popular shops in the market of Raipur city and made in laboratory.

\section{MATERIAL AND METHOD}

\section{Raw Material}

Good quality khoa was procured from Chhattisgarh State Cooperation Dairy Federation Ltd., Urla, Durg, for preparation of laboratory peda. The average composition of khoa is given in Table 1. Boora sugar and cardamom were procured from the local grocer's shop of Raipur city

\section{Preparation of Laboratory Peda}

Laboratory peda $\left(T_{1}\right)$ was prepared from fresh khoa by adopting the method as suggested by Dharampal, (1998). Khoa was taken in a non stick pan and heated at $90^{\circ} \mathrm{C}$ till pat formation with continuous stirring. Boora sugar @ 30\% and cardamom powder @ 0.5\% were added with through stirring and kneading at $50^{\circ} \mathrm{C}$ till the dough become suitable to make peda. Dough was portioned and converted into round balls by rolling between the palms and final shape was given to peda by pressing in dies. The process of flow diagram for preparation of laboratory peda was shown in Figure 1.

\section{Collection of Samples}

The market peda samples were collected from popular sweet market shops of Raipur city. Although several varieties of peda is sold in the shops but only predefined variety of peda was procured for each replication. They were designated as $T_{2}, T_{3}, T_{4}, T_{5}$ and $T_{6}$ to maintain the privacy of the source.

\section{Chemical Attributes Analysis}

The chemical quality attributes of the peda samples were tested by applying the standard methods. The moisture content of peda was estimated by drying method as per BIS: SP18, Part XI (1981), Fat was estimated by rosegottlieb method as per BIS: SP18, Part XI (1981), Titratable acidity as per IS: 1166 (1968) and total solid described by difference method.

\section{Texture Profile Analysis}

Textural profile analysis of peda samples were performed on the texture analyser (TA.XT plus, Stable Micro Systems, U.K.) and data were analyzed using software Exponent Lite fitted with a $5 \mathrm{~kg}$ load cell. TPA was done to characterize the various textural attributes like hardness, adhesiveness, springiness, cohesiveness, gumminess and chewiness of the product. The samples were cut into $1 \mathrm{~cm}^{3}$ sizes and subjected to texture analyzer. Exponent was carried out by monoaxial compression of $5 \mathrm{~mm}$ height with $5 \mathrm{~g}$ trigger force that generated plot of force $(\mathrm{g})$ versus time $(\mathrm{s}) .75 \mathrm{~mm}$ (P/75) compression platen probe was used to measure texture of set peda samples at a temperature of $25 \pm 1^{\circ} \mathrm{C}$. The force distance curve was obtained for two bite compression cycle with $1.0 \mathrm{~mm} / \mathrm{s}$ test speed with 200 pps data acquisition rate and the pre \& post-test speed were set up at $1.0 \mathrm{~mm} / \mathrm{s} \& 5.0 \mathrm{~mm} / \mathrm{s}$ respectively. 


\section{Sensory Evaluation}

Organoleptic evaluation of peda was conducted by a panel of five semi-trained judges selected from College of Dairy Technology, C.G.K.V., Raipur (C. G.), India. Peda samples were evaluated using a 100 point linear intensity rating scale. The score card suggested for khoa by Gupta and Pal, (1985) was used with some modifications for judging the product. The judges were also requested to give criticism where applicable, for each attributes of the samples.

\section{Statistical Analysis}

The data obtained were analyzed for chemical, textural and sensory attributes for market and laboratory peda samples were carried out using Statistical Analysis software SPADE (Statistical package for analysis of design of experiments, version 3.0). The data were subjected to analysis of variance (ANOVA), using by completely randomized design for chemical \& textural analysis and randomized block design for sensory evaluation was computed as described by Steel and Torrie, (1980).

\section{RESULT AND DISCUSSION}

\section{Chemical Attributes}

The results of the four replications for chemical attributes were analyzed and statistically compared among samples.

\section{Moisture Content}

The moisture content of market peda samples viz. $T_{2}, T_{3}, T_{4}, T_{5}, T_{6}$ ranged from $12.22 \%$ $\left(T_{4}\right)$ to $23.34 \%\left(T_{2}\right)$ and laboratory peda sample $12.96 \%\left(T_{1}\right)$ as shown in Table 2. It could be observed from the table that the moisture content of all peda sample differed significantly $(P<0.01)$. The variation in moisture content of peda samples might be mainly due to the difference in method of manufacturing, extent of desiccation, amount of sugar added and also difference in the chemical composition of base material used. The present findings are an accordance with Patel et al. (2011) analyzed five peda samples from different cities of Gujarat state for chemical attributes and reported significant differences in moisture content as $13.2 \%, 12.5 \%, 11.4 \%, 15.6 \%$ and $12.5 \%$.

\section{Fat Content}

The fat content of market peda samples $T_{2}, T_{3}, T_{4}, T_{5}$ and $T_{6}$ ranged from $12.26 \%\left(T_{4}\right)$ to

Table 1: Average composition of khoa

\begin{tabular}{lc}
\hline Constituent & Percentage (\%) \\
\hline Moisture & 25 \\
Fat & 30 \\
Total Solid & 75 \\
Acidity (\% LA) & 0.4 \\
\hline
\end{tabular}

Table 2: Average Chemical Compositions of Market and Laboratory Peda Samples

\begin{tabular}{|c|c|c|c|c|}
\hline \multirow[t]{2}{*}{ Samples } & \multicolumn{4}{|c|}{ Chemical Composition (per cent) } \\
\hline & Moisture & Fat & Total Solid & Acidity \\
\hline $\mathrm{T}_{1}$ & $12.96^{\mathrm{e}}$ & $17.05^{\mathrm{c}}$ & $87.04^{b}$ & $0.407^{e}$ \\
\hline $\mathrm{T}_{2}$ & $23.34^{a}$ & $14.99 \mathrm{e}$ & $76.67^{\dagger}$ & $0.365^{\dagger}$ \\
\hline $\mathrm{T}_{3}$ & $15.66^{d}$ & $15.71^{d}$ & $84.34^{c}$ & $0.632^{\mathrm{a}}$ \\
\hline $\mathrm{T}_{4}$ & $12.22^{f}$ & $12.26^{\dagger}$ & $87.78^{\mathrm{a}}$ & $0.435^{d}$ \\
\hline $\mathrm{T}_{5}$ & $22.24^{\mathrm{b}}$ & $22.58^{\mathrm{a}}$ & $77.76^{\mathrm{e}}$ & $0.515^{\circ}$ \\
\hline $\mathrm{T}_{6}$ & $20.60^{c}$ & $20.74^{\mathrm{b}}$ & $79.40^{d}$ & $0.615^{b}$ \\
\hline S Em & 0.073 & 0.046 & 0.073 & 0.007 \\
\hline F Cal & 4411.658 ** & 6866.746 ** & $4410.151^{* *}$ & 282.799 ** \\
\hline$C D$ & 0.22 & 0.14 & 0.22 & 0.02 \\
\hline
\end{tabular}

${ }^{* *}$ Significant $(P<0.01)$

The superscript $a, b, c \ldots$ are indicate the comparison various chemical attributes of peda samples values based on the $C D$ values 
$22.58 \%\left(\mathrm{~T}_{5}\right)$ and laboratory peda sample $17.05 \%$ $\left(T_{1}\right)$ was found to be highly significant $(P<0.01)$ as presented in Table 2 . The difference in the fat content of peda samples might be attributed to the variation in the type of milk used (buffalo/cow) and their fat content and duration of desiccation. The present study was in alignment with Sharma and Zariwal (1978) and Patel (1996) who reported large variation in the fat content (14.92 to $23.92 \%)$ of market samples of peda.

\section{Total Solids Content}

The total solids content in market peda samples $T_{2}, T_{3}, T_{4}, T_{5}$ and $T_{6}$ ranged from $76.67 \%\left(T_{2}\right)$ to $87.78 \%\left(\mathrm{~T}_{4}\right)$ and laboratory peda sample $87.04 \%$ $\left(T_{1}\right)$ differed significantly $(P<0.01)$ presented in Table 2. The variation in the total solid could be due to the variation in the initial total solid content of milk, method of manufacturing, variation in the initial base material used, extent of desiccation and variation in the added sugar. Miyani (1988) reported that peda

Table 3: Average Textural scores of Fresh Market and Laboratory Peda Samples

\begin{tabular}{|c|c|c|c|c|c|c|}
\hline \multirow[t]{2}{*}{ Samples } & \multicolumn{6}{|c|}{ Textural Attributes } \\
\hline & $\begin{array}{c}\text { Hardness } \\
\text { (g) }\end{array}$ & $\begin{array}{c}\text { Adhesiveness } \\
\text { (g.s) }\end{array}$ & Cohesiveness & $\begin{array}{l}\text { Springiness } \\
(\mathrm{mm})\end{array}$ & $\begin{array}{c}\text { Gumminess } \\
\text { (g) }\end{array}$ & $\begin{array}{c}\text { Chewiness } \\
\text { (g.mm) }\end{array}$ \\
\hline $\mathrm{T}_{1}$ & $1363.63^{b}$ & $-12.42^{b}$ & $0.110^{\mathrm{bc}}$ & $0.20^{a}$ & $150.59^{b}$ & $29.46^{b}$ \\
\hline $\mathrm{T}_{2}$ & $642.38^{c}$ & $-10.05^{b}$ & $0.117^{\mathrm{bc}}$ & $0.12^{d}$ & $74.85^{c}$ & $8.92^{d}$ \\
\hline $\mathrm{T}_{3}$ & $397.50^{d}$ & $-1.38^{b}$ & $0.129^{b}$ & $0.12^{d}$ & $13.08^{e}$ & $1.53^{\mathrm{e}}$ \\
\hline $\mathrm{T}_{4}$ & $3417.71^{\mathrm{a}}$ & $-70.15^{a}$ & $0.113^{b c}$ & $0.14^{c}$ & $385.41^{\mathrm{a}}$ & $53.43^{a}$ \\
\hline $\mathrm{T}_{5}$ & $595.78^{c}$ & $-10.72^{b}$ & $0.159^{a}$ & $0.18^{b}$ & $93.75^{c}$ & $16.55^{c}$ \\
\hline $\mathrm{T}_{6}$ & $507.47^{\mathrm{cd}}$ & $-6.59^{b}$ & $0.094^{c}$ & $0.14^{c}$ & $47.76^{d}$ & $6.68^{d}$ \\
\hline S Em & 61.933 & 6.499 & 0.006 & 0.005 & 7.469 & 1.296 \\
\hline F Cal & 351.016 ** & $15.493^{\star *}$ & 13.573 ** & $50.817 * *$ & 324.152 ** & 221.328 ** \\
\hline CD & 184.02 & 19.31 & 0.02 & 0.01 & 22.19 & 3.85 \\
\hline
\end{tabular}

** Significant $(P<0.01)$

The superscript $a, b, c . . .$. are indicate the comparison various textural attributes of peda samples values based on the CD values

Table 4: Average Sensory Score of Fresh Market and Laboratory Peda Samples

\begin{tabular}{lcccc}
\hline Samples & \multicolumn{4}{c}{ Sensory Attribute } \\
\cline { 2 - 5 } & Flavor(50) & Body \&Texture(35) & Color \&Appearance (15) & Total Score(100) \\
\hline $\mathrm{T}_{1}$ & $45.25^{\mathrm{a}}$ & $33.50^{\mathrm{a}}$ & $13.50^{\mathrm{a}}$ & $92.25^{\mathrm{a}}$ \\
$\mathrm{T}_{2}$ & $41.50^{\mathrm{c}}$ & $33.0^{\mathrm{ab}}$ & $13.00^{\mathrm{ab}}$ & $87.50^{\mathrm{c}}$ \\
$\mathrm{T}_{3}$ & $43.75^{\mathrm{b}}$ & $32.50^{\mathrm{bc}}$ & $12.25^{\mathrm{bc}}$ & $88.50^{\mathrm{c}}$ \\
$\mathrm{T}_{4}$ & $32.75^{\mathrm{d}}$ & $25.50^{\mathrm{e}}$ & $11.50^{\mathrm{c}}$ & $69.75^{\mathrm{e}}$ \\
$\mathrm{T}_{5}$ & $44.50^{\mathrm{ab}}$ & $31.75^{\mathrm{c}}$ & $12.75^{\mathrm{b}}$ & $89.00^{\mathrm{b}}$ \\
$\mathrm{T}_{6}$ & $43.75^{\mathrm{b}}$ & $30.50^{\mathrm{d}}$ & $11.50^{\mathrm{c}}$ & $85.75^{\mathrm{d}}$ \\
$\mathrm{S} \mathrm{Em}^{\mathrm{n}}$ & 0.39 & 0.30 & 0.250 & 0.380 \\
$\mathrm{~F} \mathrm{Cal}$ & $141.822^{* *}$ & $98.575^{\star *}$ & $34.313^{\star *}$ & $408.92^{* *}$ \\
$\mathrm{CD}$ & 1.18 & 0.89 & 0.90 & 1.15 \\
\hline
\end{tabular}

** Significant $(\mathrm{P}<0.01)$

The superscript $a, b, c \ldots .$. are indicate the comparison various sensory attributes of peda samples values based on the CD values. 
prepared from buffalo milk containing $80.78 \%$ total solid and Ray et al. (2002) reported large variation in total solid content of Kolkata market samples which ranged from 68.26 to $85.88 \%$.

\section{Titratable Acidity}

The titratable acidity of market peda samples $T_{2}, T_{3}, T_{4}, T_{5}$ and $T_{6}$ ranged from $0.37\left(T_{2}\right)$ to $0.63\left(\mathrm{~T}_{3}\right)$ percent and laboratory peda sample show $0.407 \%\left(T_{1}\right)$. Highly significant difference $(P<0.01)$ in the acidity of peda samples was observed among all the samples presented in Table 2. The significant difference in the acidity of peda samples might be the result of use of either milk with different acidity or use of fresh or stored khoa for manufacture of peda and heat treatment employed during its manufacture.

\section{Texture Profile Analysis (TPA)}

The texture is an important attribute of peda deciding it's acceptability by the consumers. The statistical analysis of various data recorded for textural characteristics of peda samples are presented in Table 3. Analysis of variance of the data pertaining to various textural attributes revealed that hardness, adhesiveness, cohesiveness, springiness, gumminess and chewiness of different peda samples showed significant changes. Detailed findings and relevant discussion is given in following paragraphs.

\section{Hardness}

In textural profile studies, hardness refers to the force required to attain a given deformation (Larmond, 1976). On a two bite force distance curve (figure 2.), it is the highest point of the peak in the first bite compression cycle. The values for hardness of fresh market peda samples varied from $397.50 \mathrm{~g}$ $\left(\mathrm{T}_{3}\right)$ to $3417.71 \mathrm{~g}\left(\mathrm{~T}_{4}\right)$ and laboratory peda sample $1363.63 g\left(T_{1}\right)$. Significant differences $(p<0.01)$ in the hardness of peda samples were observed. This variation might be due to the variation in chemical composition of the peda, amount of sugar added and extent of desiccating. These findings are in agreement with Miyani (1988) carried out rheological study on Gujarat market samples of peda and obtained average values of hardness was $2699 \mathrm{~g}$.

\section{Adhesiveness}

Adhesiveness is sometimes referred to as stickiness, which is related to how a food adheres to the palate during chewing. The average values of adhesiveness of market and laboratory fresh peda samples are given in the Table 3 . The values of adhesiveness in market peda ranged from -70.15 g.s $\left(\mathrm{T}_{4}\right)$ to -1.38 g.s $\left(\mathrm{T}_{3}\right)$ and laboratory peda sample had -12.42 g.s $\left(T_{1}\right)$. The adhesiveness was highly significant $(P<0.01)$ among the all samples. The variation could be due to the difference in raw material used, processing parameter used during manufacturing and chemical composition of peda. This is supported by Londhe et al. (2008), who studied the rheological properties of market samples of brown peda from Karnal, Mathura, Dharwad and Bangalore and reported that

\section{Khoa}<smiles>C=CC=C</smiles>

Heating at $90^{\circ} \mathrm{C}$<smiles>C1=CC=C1</smiles>

Addition of sugar @ 30\% (w/w)<smiles>C1=CC=C1</smiles>

Addition of flavor @ 0.5\% (w/w)<smiles>C1=CC=C1</smiles>

Kneading $\left(50^{\circ} \mathrm{C}\right)$<smiles>C1=CC=C1</smiles>

Cooling $\left(30^{\circ} \mathrm{C}\right)$<smiles>C1=CC=C1</smiles>

Moulding into desired shape<smiles>C1=CC=C1</smiles>

Peda

(Storage at $25 \pm 1^{\circ} \mathrm{C}$ )

Fig. 1: Flow diagram for preparation of laboratory peda (T1) 
adhesiveness as $-643.06,-1522.65,-460,-757.55$ g.sec respectively.

\section{Cohesiveness}

Cohesiveness refers to the extent to which a material can be deformed before it ruptures (Larmond, 1976). In other words, it refers to how a food product stays together after deformation. It is the ratio of the area under the second peak to that under the first peak and is unit less. The values of Cohesiveness in market peda ranged from 0.094 $\left(T_{6}\right)$ to $0.159\left(T_{5}\right)$ and laboratory peda sample had $0.11\left(T_{1}\right)$. The cohesiveness was highly significant $(\mathrm{P}<0.01)$ among the all samples presented in Table 3. These finding are in agreement to results by Prasad et al. (2012), who recorded that market peda samples differed significantly in cohesiveness value ranged from 0.214 to 0.44 of Varanasi city.

\section{Springiness}

Springiness refers to the height that the sample recovers during force relaxation time between first and second bite compression cycle (Patel et al., 2011). The overall mean values of springiness of market and laboratory samples of peda which ranged from $0.12 \mathrm{~mm}\left(\mathrm{~T}_{3}, \mathrm{~T}_{2}\right)$ to 0.20 $\mathrm{mm}\left(\mathrm{T}_{1}\right)$. The mean springiness values differed significantly $(P<0.01)$. The results agreed with Prasad et al. (2012), who recorded that market peda samples differed significantly in springiness value ranged from 0.29 to $0.42 \mathrm{~mm}$ of Varanasi city.

\section{Gumminess}

Larmond (1976) defined gumminess as the energy required to disintegrate a semi-solid food to a state ready for swallowing. It is related to primary

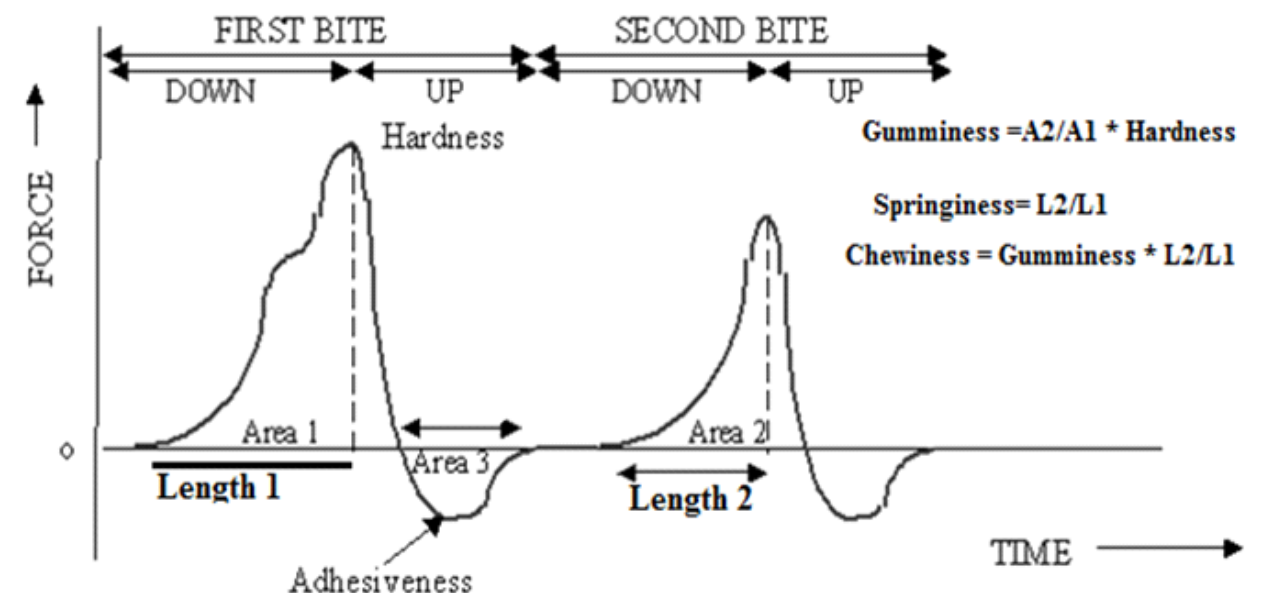

Fig. 2: A Two-bite Force Distance Texture Profile curve of the Peda Samples

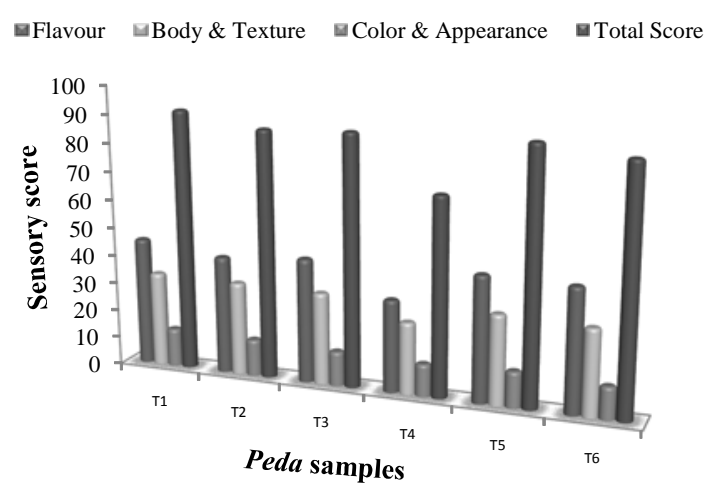

Fig. 3: Sensory quality attributes of market and laboratory peda samples parameters of hardness and cohesiveness and is obtained by multiplication of these two parameters. The mean values of gumminess of market peda which varied between $13.08 \mathrm{~g}\left(\mathrm{~T}_{3}\right)$ to $385.41 \mathrm{~g}\left(\mathrm{~T}_{4}\right)$ and laboratory peda had $150.59 \mathrm{~g}\left(\mathrm{~T}_{1}\right)$. The Mean gumminess value differed highly significantly $(P<0.01)$ among all samples. These finding are in agreement to results by Patel (1996), who reported that peda samples drawn from different cities of Gujarat had gumminess values ranged from 27.34 to $744.23 \mathrm{~g}$.

\section{Chewiness}

Chewiness refers to the energy required 
to masticate food into a state ready for swallowing and is a product of hardness, cohesiveness and springiness (Patel et al., 2011). The chewiness values differed significantly $(P<0.01)$ among samples and ranged from $1.53\left(\mathrm{~T}_{3}\right)$ to $53.43 \mathrm{~g} . \mathrm{mm}$ $\left(T_{4}\right)$ in market samples and 29.46 g.mm $\left(T_{1}\right)$ in laboratory sample. It might be due to wide variation in chemical composition of the peda samples and variation in the value of hardness, cohesiveness and springiness among samples. These finding are in agreement to results by Patel (1996) who reported the chewiness of Gujarat sample range from 1.78 to $32.81 \mathrm{~g} . \mathrm{mm}$.

\section{Sensory Evaluation}

The sensory score for market and laboratory peda samples are tabulated in Table 4. The flavor scores of peda samples $\mathrm{T}_{1}, \mathrm{~T}_{2}, \mathrm{~T}_{3}, \mathrm{~T}_{4}, \mathrm{~T}_{5}$ and $T_{6}$ ranged from 32.75 (T4) to 45.25 (T1) out of 50 score. The mean flavor value significantly differed $(\mathrm{P}<0.01)$ among each samples. The highest flavor scores were recorded in $\mathrm{T}_{1}$ and lowest flavor score recorded in $\mathrm{T}_{4}$ sample respectively. However sample $T_{1}$ on par with $T_{5}$ in terms of flavor score whereas $T_{5}$ were on par with $T_{1}$ and $T_{3}$. The highest flavor score in this peda samples might be attributed to higher fat content in this samples (Table 2). These finding are supported by Reddy (1985), who reported that an increase in flavor score of plain peda with the increase in fat content.

Body and textural scores of peda samples ranged from $25.20\left(\mathrm{~T}_{4}\right)$ to $33.50\left(\mathrm{~T}_{1}\right)$ out of 35 score. The mean body and texture value differed highly significant $(\mathrm{P}<0.01)$ among all samples. The highest and lowest body \& texture score were recorded in $\mathrm{T}_{1}$ and $\mathrm{T}_{4}$ samples respectively. However the sample $T_{1}$ on par with $T_{2}$ whereas $T_{3}$ sample on par with $T_{2}$, $\mathrm{T}_{5}$ in terms of body \& texture score. It might be due to wide variation in chemical composition particularly fat and sugar levels and variation in rheological properties particularly hardness, gumminess values of the peda samples. These findings agreed with the result of Londhe (2006), who reported that significant effect on the body and texture score of brown peda with increase in the level of fat in milk and sugar, but to a certain extent.
Color and appearance score of market and laboratory peda samples $T_{1}, T_{2}, T_{3}, T_{4}, T_{5} \& T_{6}$ ranged from $11.50\left(T_{4}\right)$ to $13.50\left(T_{1}\right)$ out of 15 score. The mean color \& appearance value differed significantly $(\mathrm{P}<0.01)$ among samples. The highest and lowest color and appearance score were recorded in $\mathrm{T}_{1}$ and $\mathrm{T}_{4}$ samples respectively. However the sample $T_{1}$ on par with $T_{2}$ and $T_{5}$ whereas $T_{4}$ sample on par with $\mathrm{T}_{6}, \mathrm{~T}_{3}$ in terms of body \& texture score. Difference in the color \& appearance score might be due to wide variation in raw material, amount of sugar added (during heat treatment reaction between sugar and amino acid produce mallard browning), method (direct \& indirect) and duration of heat treatment used for manufacture of peda. Sharma et al. (2001) reported that increase in fat percentage in khoa resulted in improvement in its color. The average total scores for market \& laboratory peda samples ranged from $92.25\left(\mathrm{~T}_{1}\right)$ to $69.75\left(T_{4}\right)$ out of 100 score. The mean total score differed significant $(\mathrm{P}<0.01)$ among each samples. The highest and lowest total score were recorded in $T_{1}$ and $T_{4}$ samples respectively. Difference in the total score might be due to wide variation in flavor, body \& texture, color \& appearance score and also variation in chemical and textural properties of peda. Among different peda samples $\mathrm{T}_{1}$ was reached with highest sensory scores for all attributes and presented in figure 3 .

\section{CONCLUSION}

The market peda samples collected from five different shops and one laboratory made peda sample in Raipur city, showed wide variation in their chemical, textural and sensory profile. This may be due to the variation in their method of preparation and varying levels of sugar and moisture content. The correlation study indicated that, there is a direct relation between moisture levels and textural variations, which affects the sensory acceptability of the peda samples.

\section{ACKNOWLEDGEMENT}

The authors are thankful to Chhattisgarh State Cooperation Dairy Federation Ltd., Urla, Durg, Raipur, for providing khoa during this investigation. 


\section{REFERENCES}

1. SP: 18, Handbook of Food Analysis, Part XI; Bureau of Indian Standards, New Delhi, (1981)

2. DharamPal, Technology of khoa based sweets CAS short course on Advances in Traditional Dairy Products. N. D. R. I. Karnal, (1998).

3. Gupta, S. K.; Pal, D. Indian Dairyman. 1985, 37, 10, 465-467

4. IS: 1166. Specifications for condensed milk, partly skimmed and skimmed condensed milk (second revision). Indian Standards Institution, Manak Bhavan, New Delhi, (1968)

5. Londhe, G. K.Development of a process for manufacture and shelf life extension of brown peda. PhD Thesis, Dairy Technology Division, National Dairy Research Institute, Deemed University, Karnal, India, (2006)

6. Londhe, G. K. and Pal, D. Indian Journal of Dairy Science, 2008, 61, 6, 347-352

7. Lormond, E.Sensory measurement of food texture. In "Rheology and Texture in Food Quality”. (Deman, J. M.; Voisey, P.W.; Rasper, V. F. and Stanley, D.W., Editors). AVI Publishing Co., USA, (1976)

8. Mahadevan, A. P. Indian Dairyman, 1991, 43, 95-101

9. Miyani, R. V. Evaluation of influence of various processing parameters on the Rheological properties of khoa and peda. A PhD. Thesis, Department of Dairy Technology., SMC
College of Dairy Science, GAU, Anand, Gujarat, India, (1988)

10. Narwade, S. G.; Bhosale, D. N.; Patange, D. D.; Londhe, G. K. and Patil, G. R. Indian Journal of Dairy Science, 2007,60, 1, 12-15

11. Patel, H. A.; Salunke, P. and Thakar, P. N. International Journal of Dairy Foods, 2011, 1, 1, 68-75

12. Patel, H. A. Comparative appraisal of quality of peda manufactured and sold in selected cities of Gujarat state. M.Sc. Thesis submitted to Department of Dairy Technology, SMC College of Dairy Science. GAU, Anand, (1996)

13. Prasad, R.; Jha, A.; Jha, A. Journal of Dairying Foods and Home Science, 2012, 31, 4, 239243

14. Ray, P. R.; Bandyopadhyay, A. K.; Ghatak, P. K. Indian Journal of Dairy Science, 2002, 55, 2, 83-85

15. Reddy, C. R. Process Modification of production of khoa basd sweets. Ph. D. Thesis, Kurukshetra University, Kurukshetra, (1985)

16. Sharma, U. P.; Zariwala, I. T. Journal of food Science and Technology, 1978, 15, 118-121.

17. Sharma, H. K.; Singhal, R. S.; Kulkarni, P. R. Internatinal journal of Dairy Technology. 2001 54, 107-110

18. Steel, R. G. D. and J. H. Torrie Principles and Procedures of Statistics-a Biometrical Approach, $2^{\text {nd }}$ edn, New York: McGrawHill.(1980) 